\title{
Does Rebranding As Name Change Rebuild Or Destroy Brand Equity (Customer Loyalty And Brand Reputation) After Brand Crisis?: The Case Of Malaysian Airline System (MAS)
}

\author{
Okechukwu Worlu $^{1}$, Roslizawati Ahmad ${ }^{2 *}$ \\ ${ }^{1}$ Okechukwu Worlu, \\ Universiti Utara Malaysia, Kedah, 06010, MALAYSIA \\ ${ }^{2}$ Roslizawati Ahmad, \\ INTI International College Penang, Penang, 11900, MALAYSIA
}

*Corresponding Author

DOI: https://doi.org/10.30880/jtmb.2019.06.02.002

Received 24 July 2018; Accepted 10 March 2019; Available online 30 June 2019

\begin{abstract}
This paper explored on rebranding, brand reputation and customer loyalty. The purpose of this research study was to examine rebranding as a tool to rebuild brand reputation and restore customer loyalty after brand crisis in the Malaysia airline. The study utilized quantitative research design method to gather data from 375 respondents from the northern region of Malaysia. Seven Likert scale was used to measure the rebranding, brand reputation, and customer loyalty constructs. Statistical Package for the Social Sciences (SPSS) 20.0 was utilised to analyse the collected data. The finding affirmed that rebranding significantly rebuilds brand reputation after brand crisis. Additionally, the outcomes of this study equally revealed that rebranding significantly restore customer loyalty after brand crisis. This paper presents significant theoretical contribution for the academic knowledge purpose and practical contributions for practitioners, in making clear decisions before embarking on rebranding exercise.
\end{abstract}

Keywords: Rebranding; brand reputation; customer loyalty 


\section{Introduction}

Rebranding organisation products, goods and services are very difficult, challenging, and risky. However, rebranding on the other hand, represents the most impressive aspect that will change the face of the organization for good (Kapferer, 2004). In decades, organizations' brand reputation has dropped in its values, trust, loyalty, relevancy and marketplace. As a result, influence numbers of organization to acknowledge rebranding (Opuni, Baffoe \& Adusei, 2013). Rebranding is the act of redirecting the brand identity without demolishing the current brand trust known by the consumers (Keller, 1999); it is an ongoing development whereby an organization replies to its dynamics in the business environment by changing their identity for surviver and improvement (Tevi \& Otubanjo, 2013). Rebranding rebuilds an existing brand to a fresh brand identity, and its aim is to stand out it location differently in the mind of the external stakeholders as well their competitors (Muzellec et al., 2003) and it is the answer to react to a brand that loses its reputation and value in the minds of the consumers and marketplace (Teh, 2009).

Rebranding is done in order to redirect how consumers perceive the existing brand and reinstate a tarnished brand loyalty (Muzellec \& Lambkin, 2006; Hankinson \& Lomax, 2006). On the contrary, researcher like Collange, (2014) believed that rebranding involving name change will destroy the reputation of the organization. This claim has been supported by Roy and Sarkar (2015) study which relates the negative effect of rebranding on the brand associations among the stakeholders. The practice of rebranding is classified in three different stages, small change as aesthetics, medium change as repositioning and full change as rebranding (Daly \& Moloney, 2004). And its practice can occur in three different levels in an organization; corporate level, business unit level, and product level (Muzellec \& Lambkin, 2003). The setting of this study is airline service in Malaysia, particularly Malaysian Airline System (MAS) currently known as Malaysian Airline Berhad (MAB). An airline rebranding processes need to take into consideration carefully by any of the airline's country-of-origin brand, especially airline that represent as country flag-carrier. Such airline brands ought to understand their consumer's perception of the brand before the rebrand (Sackett \& Kefallonitis 2003). Building on the literature related to rebranding, brand reputation, and customer loyalty after the brand crisis, this study attempt to examine whether rebranding as name change rebuilds and restore brand reputation and customer loyalty or destroys brand reputation and customer loyalty after the brand crisis.

\subsection{Background of the study}

Various definition of a brand crisis has been made in the literature. In term of linguistic, the word of crisis is originated by Greek word "krisis" which is also the same use in Bahasa Malaysia means judgement, choice or decision (Paraskevas, 2006). Priporas and Vangelinos (2008) as cited in Fink (1986) study defined crisis as "an unstable time or state of affairs in which a decisive change is impending-either one with the distinct possibility of a highly undesirable outcome or one with the distinct possibility of a highly desirable and extremely positive outcome". Brand crisis on product harm has been defined as "discrete, well-publicized occurrences wherein products are found to be defective or dangerous" (Dawar \& Pillutta, 2000). From a global perspective, the globalization of market influenced the increasing of brand crisis (Rea, Wang, \& Stoner, 2014; Meulenberg et al, 2002). Brand crisis can be caused in many forms, either internally or externally such as natural disasters, technology defect, labour strike, terrorism, product corrupting and corporate espionage (Priporas \& Vangelinos, 2008). Good brand reputation is the competitive advantage to the organization and it can protect the organization during the brand crisis occur (Sengupta, Balaji, \& Krishnan, 2015; Selnes, 1998).

Several studies and reports have discussed on the airline service crisis in different settings. The World Airline Report states several reasons such as rapid globalization, increased fuel prices, an occurrence of natural disasters, threat of accidents, increased security insurance and deregulation policies to impact the world's airline industry" (Flint, 2010). "The everchanging landscape of world's airline industry coupled with the existing tough situations have been sending out signals to the airline industry to revamp the traditional strategies and venture into new alliances and business models in order to gain the benefits of competitive advantage and effective positioning" (Adapa, \& Roy, 2017). In corresponding to the tough situation faced by airline industries, the Malaysian Airline Berhad (MAB) formally known as Malaysian Airline System (MAS) has faced tragedy and sorrow incident happened in the year 2014, which have created a tremendous history to the airline's industry. MAS recorded two incidents in a year started with the missing of MH370 on 8 March 2014 and the crashed of MH17 on 18 July 2014 at Donetsk region, Ukraine (Malaysian Airlines System [MAS], 2014). The double incidents leave a negative impact on the sale and reputation of MAS. MAS recorded a Net Loss of RM307 million for the three months ended 30 June 2014 and 65\% drop than the previous corresponding year, 2013. For the three months ended June 2014, MAS Group revenue fell 5\% to RM3.59 billion compared to one year ago (MAS, 2014). The tremendous drop in the sale of MAS tickets is the effect of the crisis and consumers doubt on the safety aspect of their services.

The crisis has tarnished their reputation and it leads to the sale reduction (Raghuvanshi $\& \mathrm{Ng}, 2014$ ). And according to MAB (2016) press room, "2nd quarter is expected to be weaker and the Group expects to record a loss for the year 2016". This indicates that past incidents still affect organization profits and market shares. The two tragedies happened to MAS which lead to the rebranding as a name change to MAB in 2016 is articulated as brand crisis based on the literature definition. Few reports have portrayed that two tragedies happened in 2014 which claimed a total of 537 lives, the airline announced a five-year recovery plan which has so far resulted in the Malaysian government taking full ownership of the company. The issue of loss of revenue has also lead the MAB to reduce their employees from 20,000 to 14,000 as part of a huge cost-cutting 
exercise" (Anthony, 2015); The competition among the airline service companies has become worst after Malaysia implemented the Open Skies policy in 2015 (ASEAN Briefing, 2015); the accidents such as the mysterious disappearance of MH370 and the fatal accident of MH17 led to insecurity and reduction to most public to take MAS for air travel despite that Malaysia has been cited as the most visited destination by 28 million tourists in 2014 (Adapa, \& Roy, 2017). Further report by the Malaysian Airlines Chief Executive Officer (CEO), Christoph Mueller mentioned to the news conference in 2015 that "that the airline was already struggling against strong regional competition and had made a loss for several years that before it was struck by two separate disasters in quick succession" (British Broadcasting Corporation [BBC], 2015). The reputation of the airlines' organization will determine the sustainability and profitability of the organizations in the airline's industry and reputation is the key factor for the customer loyalty (Mohd Johan, Mohd Noor, Bahar, Yan, \& Ping, 2014). Researcher Greyser (2009), "brand crisis could be caused by (i) product failure, (ii) social responsibility gap, (iii) corporate misbehaviour, (iv) executive misbehaviour, (v) poor business results, (vi) spokesperson misbehaviour and controversy, (vii) loss of public support or (ix) controversial ownership." George, Amalia, Aikaterini, and Ioannis (2010) stated brand crisis due to the service failure and product recall usually give a negative impact on the publicity of the organization. End users or customers learn and experience the firm's harmful services and the crisis, which can severely damage its corporate image. However, not only damaging the brand reputation also will affect the profit and market share of the organization (Siomkos \& Kurzbard, 1994; Yubo, Shankar, \& Yong, 2009). More importantly, will affect the investor's confidence towards the ability of the organization which might make the investor suspended the funding to the organization (Yubo et al., 2009).

A brand crisis will affect the goodwill of the brand. The impact of the crisis will directly influence customer loyalty towards the brand and it will lead the customer to consider another brand for the same product as their choice (Papadakis, 2006). Customer loyalty is the vital survival factor for organization especially in term of the competitive advantage and market share in which brand loyalty will help increase organization's competitive advantage and market share (Dick \& Basu (1994). To rebuild brand reputation, regain customer loyalty, and increase organization profits, studies have claimed that rebranding is needed (Le, Cheng, Kuntjara, \& Lin, 2014; Collange, 2014; Zahid et al., 2014; Chu et al., 2014 Reddy, Reddy, $\&$ Venkatesulu, 2016). Numerous studies have informed on the negative effects of brand crisis on brand reputation, effect on corporate image, effect on organization publicity, the reduce of profits and market shares, brand crisis affecting the investor's confidence (Papadakis, 2006; George, et al., 2010; Siomkos \& Kurzbard,1994; Yubo et al., 2009); the significant role of customer loyalty on organization survival in the competitive environment (Dick \& Basu, 1994) and the need of rebranding to rebuild brand reputation, reinstate customer loyalty, and increase organization profits (Borges \& Branca, 2010; Singh, Tripathi \& Yadav, 2012; Kumar, Pasha \& Prakash, 2015; Goi, 2012; Makasi, Govender \& Madzorera, 2014). But, there seems to be limited study exist on rebranding as name change rebuild or affects brand reputation and customer loyalty after the brand crisis in the Malaysian airline service sector, specifically MAB. Due to the airline service failure and crisis of reduction of revenue which proclaimed to led to bankrupt as mentioned by Malaysian Airlines Berhad, CEO in news conference; the less confidence and insecure to use the airline to fly by the public's (Adapa, \& Roy, 2017); and the need for MAS rebranding exercise mentioned by Mueller (BBC, 2015), it is important to focus on this MAB airline service in order to investigates whether the rebrand carried out rebuild or affects the brand reputation and customer loyalty after the crisis, to provide practical information's that can support other practitioners who aim to embark on rebranding their existing brand with the aims to rebuild the tarnished brand reputation, restore customer loyalty, and increase organization profits and market shares. Furthermore, it is important to carry out this study in rebranding as a name change, rebuild or affects brand reputation and customer loyalty after the brand crisis in the Malaysian airline service sector, to diminish the crisis.

Theoretically, to address the argument made in literature which Muzellec and Lambkin (2006) believed that the rebranding strategy which involved the name changes will varnish the positive brand reputation that the brand usually stimulates to the customers, while on the other hand, Makasi, Govender and Madzorera (2014) claimed that rebranding with a better move will rebuild organization tarnished brand reputation and sustain customer loyalty. To address this argument made in past studies, few questions were compulsory. These questions are as follows; does rebranding as name change rebuild brand reputation?; does rebranding as name change restore customer loyalty?. Based on the argument made in literature, the objectives of this research was to examine whether rebranding as name change rebuild brand reputation and restore customer loyalty after brand crisis.

\section{Literature Review}

In this study, reciprocity theory is used to underpin the brand reputation and customer loyalty related to the reaction resulting from rebranding taken by the organization that can influence consumers to switch to the other brand with unfriendly behaviour. "Researchers have supported their views by showing that reciprocity is an influential factor in human behaviour; empirical evidence, questionnaires used by psychologists and economists and notable texts in sociology, ethnology and anthropology have highlighted the presence of reciprocal conduct" (Al-Refai, 2015: p. 76). The focal point of reciprocity theory is how people evaluate the kindness of action after considering the underlying intention (Falk \& Fischbacher, 2006). Relating to this study, customer evaluation refers to the customer's loyalty after the rebranding has been implemented by the organization. This evaluation will lead to reciprocal action which is either the customer will display kindness by being loyal to the organization or being unkindness by switching the other brand. 


\subsection{Rebranding}

As pointed out already, the term "rebranding" has been widely used in the business press (Jarvis, 2001; Lentschner, 2001; Brook, 2002; Harrison, 2002; McGurk, 2002; Dickson, 2003) and scarcely at all in academic publications (Griffin, 2002; Kaikati, 2003; Stuart and Muzellec, 2004). Rebranding is an important key strategy for organizations to achieve or reinstate brand values that have been out of date or tarnished (Zahid \& Raja, 2014). Rebranding is the change between the initial brand to a new formulation of the brand in the mindset of the consumer and the marketplace (Merriless \& Miller, 2008). Basically, rebranding has an effect on consumer's perception, especially in the case of revolutionary rebranding (Ing, 2012). It can be summarized that rebranding occurs due to organization aims. Organizations undergo rebranding because of changing their level of position and intend to upgrade its communication with the internal and external stakeholders as well to stay relevant in the marketplace. Muzellec et al. (2003) believed that the practice of rebranding is building again, a name representative, and distinctive identity from competitors. However, Hankinson and Lomax (2006) posits that if organizations could be more capable in communication with their internal stakeholders, then their rebranding process will positive influence the external stakeholders. For this reasons, organisation rebranding should be given more time to surround its exercise in the minds of the internal stakeholders for a clear understandable that will support in building long-term loyalty and reputation (Hankinson, et al.,2007). Giving extensive time to rebranding can be a supportive hand to organizations in following the right steps for their rebranding exercise, because it is a difficult exercise of which organizations might fail or success. The paper hopes to identify rebranding impact on brand reputation and customer loyalty after the brand crisis of airline in Malaysia to add new knowledge to marketing and brand literature of Asian context. As well support the practitioners acknowledging the dynamic impact of rebranding to rebuild and restore reputation and loyalty after crisis in airline industry.

\subsection{Rebranding and Brand Reputation}

In linguistic explanation, the word of reputation brings the meaning of the estimation of consistency over time of the quality of an organisation (Herbig \& Milewicz, 1997). Referring to the linguistic explanation, brand reputation has been defined as the estimation by a customer of the consistency of product or service' quality associated with the brand name (Sengupta, Balaji, \& Krishnan, 2015; Zayerkabeh, Albabayi, \& Abdoli, 2012; Selnes, 1998). The development of brand reputation is based on the subjective evaluation of product or services quality offered by the organization (Rhee, 2009). At first sight, rebranding practice seems to oppose the marketing and corporate reputation literature (Muzellec \& Lambkin, 2006). To maintain the brand reputation and customer loyalty, rebranding has become one of the significant approaches to be successful (Zahid \& Raja, 2014). Marketers see rebranding as an active approach to reinstate the obsolete brand (Petburikul, 2009). With this statement, this study hypothesized that:

\section{H1. Rebranding have the significantly influence to rebuild brand reputation}

\subsection{Rebranding and Customer loyalty}

Several studies in the marketing brand literature have proficiently conceptualised the relevance of customer loyalty. According to Aaker (1996), brand loyalty is the key factor of brand equity. Brand equity has been defined by Kotler, Keller, Ang, Leong, \& Tan (2012) as the reflection of how customers think, feel and act with respect to the brand and its prices. Brand loyalty has been defined as a behaviour or attitude uphold by the customer towards the buying intention for a specific brand. The behaviour of patronize or repurchase a preferred brand is the foundation in defining the term of brand loyalty (Bowen \& McCain, 2015; Veloutsou, 2015; Oliver, 1999). Brand loyalty is also an emotional or psychological attachment to brand within a product class (Ahluwalia, Burnkrant, \& Unnava, 2000). Actually, rebranding has its own risks sometimes and can affect customer loyalty and equity (Keller, 1993). Customers might not appreciate the rebrand and might as well feel deceived when the brand's perceived value disappears after the rebranding (Haig, 2003). However, without offering something new, rebranding logo, the name of aesthetics would not bring much good success (Goi \& Goi, 2011). This means that customer loyalty is related to rebranding. Based on the evidence from literature as reviewed in this section, rebranding of a name of any aspect of organisation it perceived as a factor that can influence consumer's loyalty positively or negatively depending on the present situation. With this reason, this study further hypothesized that:

\section{H2. Rebranding have the significantly influence to restore customer loyalty}

\section{Methodology}

This study used descriptive research to identify whether rebranding rebuilds or affects brand reputation and customer loyalty after the brand crisis in the Malaysian airline service sector, practically on MAB. The target population for this research is the passengers of the airlines' services in the Northern Region of Peninsular Malaysia (Perlis, Kedah and Penang). 
Perlis, Kedah and Penang have been choosing because there is one international airport (Penang International Airport) and one domestic airport (Sultan Abdul Halim Airport). The respondents from two airports have the same characteristics of all airlines passengers which are relevant to this research. Malaysian Ministry of Transport (2015) reported that total passengers in these two airports of Northern Region namely, Sultan Abdul Halim Airport, Kedah and Penang International Airport were 6,251,955 and 719,029 passengers respectively (include International and Domestic). 384 sample size is qualified to represent the overall 6,970,984 passengers from the two-airport based on Krejcie and Morgan (1970). Table 1 total passengers handled by two North Region Airport, Malaysia involved in this study.

Table 1 - Total Passengers Handled by North Region Airport, Malaysia (as of 2015)

\begin{tabular}{ll}
\hline Airport & Total Passengers \\
\hline Penang & $6,251,955$ \\
Kedah & 719,029 \\
\hline Total & $6,970,984$ \\
\hline
\end{tabular}

Sources: Malaysian Ministry of Transport (2015)

The quantitative research design of questionnaire form was used to gather the data from the respondents because this study incorporates different variables (i.e. rebranding, brand reputation and customer loyalty). A Personally administration method was used for distributing the questionnaires. The technique used was by approaching the passengers face to face to assist in taking part in the research survey. The questionnaires were given out by hand to hand to the passengers. 400 questionnaires were distributed in Penang International Airport (number of respondents needed is 196) and 368 in Sultan Abdul Halim Airport, Alor Setar (number of respondents needed is 186). A sample size of more than 30 and less than 500 is also appropriate and suitable for most research based on Sekaran (2003). The total number of respondent was doubled from 384 to 768 in order to reduce non-response error (Hair et.al, 2006). According to Creswell (2013), a quantitative research method is important to generate measurable causes and effect relationship between the variables. In collecting data, the eight (8) items of rebranding were adapted from Walsh (2005), with reliability score was Cronbach alpha $=0.95$. Ten (10) items of brand reputation were adapted from Mason (2014) based on Kim's Organization reputation scale. The researcher made amendments on the item by replacing the word of an organization to the brand name. Reliability result of Cronbach alpha $=$ 0.90. And the seven (7) items of customer loyalty were adapted from Chaudhuri and Holbrook (2001).

Brand loyalty will be measured in two dimensions (i) attitudinal measurement (ii) behavioural measurement. Its Cronbach's alpha score on behavioural loyalty was 0.90, and the attitudinal loyalty is 0.83 . Based on Zikmund et al. (2003) study on Cronbach's alpha recommendation, the coefficient alpha of 0.70 and above indicates good reliability. Which means that all items adapt for this research are reliable and accepted to use for developing and measuring the items set for this study. Seven Likert scales were used to measure all items of rebranding, brand reputation, and customer loyalty of this study. The seven Likert scale is range from $1=$ strongly disagree and $7=$ strongly agree. A nominal scale was used to attain the respondent profile of eight (8) items. The technique used in analysing the data collected was descriptive statistics. Frequency distribution test was conducted on respondents demographic. As according to Sekaran (2003), a descriptive statistic of a frequency distribution is used to obtain all personal data or classificatory variables of a study. The reliability test was run to check whether the items measured are consistently correlating to one another. As suggested informed Sekaran, (2003), reliability Cronbach's alpha is need when measuring the internal consistency of the position of items. And the Cronbach's alpha limit of 0.70 is mostly accepted by researchers (Nunnally, 1975). Correlation analysis was conducted to test the relationship between all the variables. According to Cohen (1988), the range and strength of the correlation's coefficient can be distinguished from the following rule of thumb $(+.10$ to +.29 is small, +.30 to +.49 is medium and +.50 to +1.0 is large). Statistical Package for the Social Sciences (SPSS) 20.0 was used to analyse the data.

\section{Results}

This study found 218 respondents were female, while 154 respondents indicate to be the male. The ages from 25-35 are shown to be the highest of 160 respondents, followed by the ages of 36-46 of 133 respondents, and the ages between $47-57$ of 70 respondents, and the ages from 58 and above was 9 respondents. 17 respondents were from high school, 53 were bachelor degree, 171 were the master degree, and 131 were $\mathrm{PhD}$. The numbers of single respondents are most elevated with a high record of 337. The married respondents were 35 in total. The study found a higher number of 303 respondents were Malaysian, and 69 respondents were Non-Malaysian. 195 respondents were government servant, 101 are a private worker, 59 were self-employed, and 17 were retired. 154 respondents prefer to fly with Malaysian Airline Berhad, 119 respondents prefer flying with Air Asia, while 99 prefer flying with other airlines. 273 respondent fly with the airline once a year, 91 flies with the airline once a month, while 8 flies once a week. 


\subsection{Reliability Results}

This section presents all results found during the data running with use of the SPSS 20.0 program. Reliability result was shown first. The objectives of this study were to identify the influence of rebranding on brand reputation and brand loyalty. Table 4 present the total reliability results on the variables.

Table 3 - Reliability Statistics Test

\begin{tabular}{ccc}
\hline \multicolumn{3}{c}{ Reliability Statistics } \\
\hline Variables & Cronbach's Alpha & No. of Items \\
Rebranding & .956 & 9 \\
Brand & .940 & 10 \\
Reputation & & \\
Brand & .938 & 7 \\
Loyalty & & \\
\hline
\end{tabular}

Referring to table 3, the reliability ( $\alpha=0.956)$ measured on rebranding 9 items, $(\alpha=0.940)$ measured on brand reputation 10items and the $(\alpha=0.938)$ measured on brand loyalty 7 items shows that all variable items measured have maintained internal consistency. These items were accepted of Cronbach's alpha .90 is considered excellent for research study recommendation by Nunnally (1975).

\subsection{Correlation Results}

This section analysis presents the correlation analysis. Correlation analysis was conducted to inspect the relationship between independent variables and dependent variable. Note that all decision on the statistical significance of the results were made by utilizing an alpha level of 0.05 . Hypothesis 1 was first analyzed and presents in Table 4.

\section{Table 4 - Correlations Result of Rebranding and Brand Reputation}

\begin{tabular}{|c|c|c|c|}
\hline & & Correlations & \\
\hline & & $\begin{array}{l}\text { Rebranding } \\
\text { (RB) }\end{array}$ & $\begin{array}{l}\text { Brand } \\
\text { Reputation } \\
\text { (BR) }\end{array}$ \\
\hline \multirow[t]{3}{*}{$\mathrm{RB}$} & $\begin{array}{l}\text { Pearson } \\
\text { Correlation }\end{array}$ & 1 & $.276^{* * *}$ \\
\hline & Sig. (2-tailed) & & .000 \\
\hline & $\mathrm{N}$ & 372 & 372 \\
\hline \multirow[t]{3}{*}{$\mathrm{BR}$} & Pearson & $.276^{* *}$ & 1 \\
\hline & $\begin{array}{l}\text { Correlation } \\
\text { Sig. (2-tailed) }\end{array}$ & .000 & \\
\hline & $\mathrm{N}$ & 372 & 372 \\
\hline
\end{tabular}

The study found $\mathrm{r}=0.276, \mathrm{p}<.000$ on rebranding and brand reputation. Though, Pearson correlation established a low strength of the relationship between rebranding and brand reputation. But there is a significant relationship between rebranding and brand reputation of 0.01 value as shown in Table 4. 
Table 5 - Correlations Result of Rebranding and Customer Loyalty

\begin{tabular}{|c|c|c|c|}
\hline \multicolumn{4}{|c|}{ Correlations } \\
\hline & & $\begin{array}{l}\text { Rebranding } \\
\text { (RB) }\end{array}$ & $\begin{array}{l}\text { Customer } \\
\text { Loyalty (CL) }\end{array}$ \\
\hline \multirow[t]{3}{*}{ RB } & Pearson & 1 & $.270^{* *}$ \\
\hline & $\begin{array}{l}\text { Correlation } \\
\text { Sig. } \\
\text { tailed) }\end{array}$ & & .000 \\
\hline & $\mathrm{N}$ & 372 & 372 \\
\hline \multirow[t]{3}{*}{ CL } & $\begin{array}{l}\text { Pearson } \\
\text { Correlation }\end{array}$ & $.270^{* *}$ & 1 \\
\hline & $\begin{array}{l}\text { Sig. } \\
\text { tailed })\end{array}$ & .000 & \\
\hline & $\mathrm{N}$ & 372 & 372 \\
\hline
\end{tabular}

The study found $r=0.270, p<.000$ on rebranding and customer loyalty. The result established a low strength of the relationship between rebranding and brand reputation of Pearson correlation. However, there is a significant relationship between rebranding and customer loyalty of 0.01 value as shown in Table 5 .

\subsection{Regression Analysis}

Testing the research hypotheses of the constructs in this study, we utilized standard multiple regression methods to allow the calculation of all variables at a time. The results found were based on passenger's response. The analysis was carried out on rebranding as a strategy to rebuild and restore brand reputation and customer loyalty. Based on the hypotheses result, the findings supports $\mathrm{H} 1$ rebranding have the significantly influence to rebuild brand reputation ( $\beta=$ $0.276 ; \mathrm{t}=5.518, \mathrm{p}<0.000)$. The finding further revealed that rebranding significantly rebuild brand reputation $(\beta=$ $0.270 ; \mathrm{t}=5.383, \mathrm{p}<0.000$ ) which is reliable with $\mathrm{H} 2$ of this study.

Table 6 - Hypotheses Test Summary

\begin{tabular}{llll}
\hline HYPOTHESES & $\begin{array}{l}\text { Beta } \\
(\boldsymbol{\beta})\end{array}$ & $\begin{array}{l}\text { t-value } \\
(\mathbf{t})\end{array}$ & RESULTS \\
\hline $\mathrm{H}_{1}$ & 0.276 & 5.518 & Accepted \\
$\mathrm{H}_{2}$ & 0.270 & 5.383 & Accepted \\
\hline
\end{tabular}

\section{Discussion}

The general objective of this study is to examine whether rebranding as name change rebuilds brand reputation and restore customer loyalty after brand crisis. This chapter discusses the achieved significant results and hypothesis tested. The result found in the first regression test shows that rebranding does rebuild brand reputations after the brand crisis. Although the strength of the relationship between rebranding and brand reputation seem to be low, yet there is a significant relationship between rebranding and brand reputation, which have answered the first research question, achieved its research objective, and justified the research hypothesis. The result found in the second regression analysis test also shows that rebranding does restore customer loyalty after the brand crisis. The strength of the relationship between rebranding and customer loyalty was equally, however, there is a significant relationship between rebranding and customer loyalty, which have answered the second research question, achieved the research objective, and justified its research hypothesis.

Potentially, this study addresses the argument raised within few scholars, which states that rebranding rebuilds brand reputation and customer loyalty by Makasi, et al. (2014) and the clime that rebranding destroys the brand reputation and customer loyalty (Muzellec \& Lambkin, 2006; Collange, 2014; Roy \& Sarkar, 2015). Though, there were crisis effects on MAB last 2 years ago, due to the incidents that happened in 2013-2014 which resulted in the competition among the airline service companies (ASEAN Briefing, 2015); slowdown of public use of the Malaysia airline system to travel (Adapa, \& Roy, 2017); drop of group revenue (MAS, 2014) that result to rebrand as name change. However, a convincing number of $154(41 \%)$ passengers prefer to fly with MAB compare to the 218 passengers who prefer flying with Air Asia and other flights highlights in section 4.2. this have shown that rebranding significantly rebuild brand reputation and restore customer loyalty. This research findings is in accordance with Makasi 
et al. (2014) claim, by positing that a good rebrand move will rebuild brand reputation and reinstates customer loyalty. However, it contradicts other claims which state that rebrand destroys the brand reputation and customer loyalty (Muzellec \& Lambkin, 2006; Collange, 2014; Roy \& Sarkar, 2015). Based on the achieved findings and discussion, contributions were made. These contributions are separated into theoretical and practical contribution. The contributions are significant to the researchers and practitioners of any industries. The theoretical contributions of this study clarify the argument made that rebranding rebuild or destroy the brand reputation and customer loyalty in previous studies (Muzellec \& Lambkin, 2006; Collange, 2014; Roy \& Sarkar, 2015; Makasi, et al., 2014; Le, et al., 2014). Theoretically, it informs that rebranding rebuild brand reputation and reinstates customer loyalty of MAB. In addition, the positive results were realized with the support of the reciprocity theory proposed by Falk and Fischbacher, (2000-2006). Consequently, the theory is acknowledged significant for the judgement of customer loyalty, brand reputation after rebranding.

Discussing in practical perception, the contribution of this research can assist organizational management to understand the type of rebrand need to rebuild their brand reputation and reinstates customer loyalty after the brand crisis. Also, the factors of rebranding that can rebuild brand reputation and restore customer loyalty after the brand crisis. It can support the organization to understand to what extent does the rebranding rebuild, restore and increases the revenue and market shares for the benefit of the organization and customers. In addition, it also helps to inform the organization that rebranding is an effective key to react to the brand crisis if it occurs in their business. There are some limitations that need to be considered in this research. As this research aims to examine whether rebranding rebuilds and restore brand reputation and customer loyalty after the brand crisis. This study was limited to two airports, Sultan Abdul Halim Airport, Kedah and Penang International Airport in the Northern Region of Malaysia only, whereas there are other airport and regions of Malaysian. This study focused on the Malaysian airline service sector only, while excluding other sectors in the Malaysian industries which crisis might exist. The passengers as gen $\mathrm{Y}$, gen $\mathrm{X}$ and millennials were used to gather the data. However, the results were not generalized to all passengers of airlines service within Malaysian. Nevertheless, these limitations were able to serve as an underpinning for future research in other airport, airlines organization or sectors which crisis do exist. Due to this study limits, few recommendations for future study were derived. It is recommended that this research should be extended to other parts of Region in Malaysia, such as Central Region, Southern Region, and East Coast Region that have an airport with passengers in order to increase the understanding of rebranding, brand reputation, and customer loyalty after crisis to generalize the result. Future research of similar settings should be done in other sectors such as tourism, banking, and manufacturing sector in the Malaysian industries and other countries were crisis exist in order to confirm whether rebranding as name change rebuilds brand reputation and restore customer loyalty after crisis. It is recommended that study should also focus on millennial generation that uses airlines as part of their travel medium, to identify the level of customer loyalty after rebrand and its effect on brand reputation after a crisis. These recommendations were made to cover the gap that the study could not be able to accomplish, hoping that further study will continue this as longitudinal research for more convincing results.

\subsection{Conclusion}

Generally, the purpose of this study is to examine whether rebranding as name change rebuilds brand reputation and restore customer loyalty after brand crisis. Rebranding with better moves can rebuild brand reputation and restore customer loyalty after the brand crisis. This study analysed the effect of rebranding to the brand reputation and customer loyalty based on the real tragedies of Malaysian Airlines Berhad (MAB). The findings revealed that the rebranding has a significant relationship with brand reputation and customer loyalty. Though MAB rebranded the brand, it not leave any effect on the brand reputation and customer loyalty. These findings have contributed to the body of knowledge. This study also concludes that other organization in different sectors who face a crisis, need to consider the rebranding implementation after the crisis which it can help to rebuild brand reputation and restore customer loyalty. Customer loyalty is equally vital to organization's brand. Restored customer loyalty will rebuild brand reputation. Conclusively, the empirical evidence found in this study can be used for future research, it also can be assisting guide to the organization exercising rebranding to rebuild brand reputation and reinstate customer loyalty.

\section{References}

Aaker, D. (1996). Building strong brand. New York City: Free Press

Adapa, S., \& Roy, S. K. (2017). Case Study 6: Malaysian Airlines Versus AirAsia: Customer Satisfaction, Service Quality and Service Branding. In Services Marketing Cases in Emerging Markets (pp. 67-

75). Springer International Publishing.

Ahluwalia, R., Burnkrant, R. E., \& Unnava, R. H. (2000). Consumer response to negative publicity: moderating role of commitment. Journal of Marketing Research, 203-214. 
Al-Refai, A. N. (2015). Factors influencing customer's loyalty of mobile service provider among generation Y. Doctoral Dissertation: University Utara Malaysia.

Borges, M. \& Branca, A. (2010). The mpact of corporate rebranding on the firm's market value working paper. Lisbon: Technical University

Bowen, J. T., \& McCain, S.-L. C. (2015). Transitioning loyalty Programs : A Commentary on "The Relationship Between Customer Loyalty and Customer Satisfaction". International Journal of Contemporary Hospitality Management, Vol. 27 Iss 3 pp. 415-430.

Burns, A. C., \& Bush, R. F. (2002). Marketing research: Online research applications. New Jersey: (4th ed.) Prentice Hall.

Chaudhuri, A., \& Holbrook, M. B. (2001). The Chain of Effects from Brand Trust and Brand Affect to Brand Performance: The Role of Brand Loyalty. Journal of Marketing , 81-93.

Chu, Lee, Yeu \& Park. (2014). How much change is optimal when a brand is newly rebranded. Asia Marketing Journal, 15 (4), 161-186.

Churchill, G. A., \& Iacobucci, D. (2004). Marketing research: Methodological foundations. 9th ed. South Western Ohio: Thomson.

Creswell, J. W. (2013). Research design: Qualitative, quantitative, and mixed methods approach. Sage Publications.

Daly, A., \& Moloney, D. (2004). Managing corporate rebranding. Irish Marketing Review, 17 (1/2), 30-31.

Dawar, N., \& Pillutta, M. (2000). Impact of product-harm crises on brand equity: the moderating role of consumer expectations. Journal of Marketing Research, Vol. 37 No. 2, pp. 215-226.

Dick, A. S., \& Basu, K. (1994). Customer loyalty : Toward an integrated conceptual framework. Journal of The Academy of Marketing Science, 99-113.

Falk, A., \& Fischbacher, U. (2006). A theory of reciprocity. Games and Economic Behavior , 293-315.Flint, P. (2010). World Airline Report. Air Transport World, July: 24-33.

George, S., Amalia, T., Aikaterini, V., \& Ioannis, T. (2010). Opportunities and threats for competitors in product-harm crisis. Marketing Intelligence \& Planning, 770-791.

Goi, C., \& Goi, M. (2011). Review on models and reasons of rebranding. In International conference on social and humanity, IPEDR, Vol. 5.

Goi, M. (2012). Rebranding and Impact toward Brand Equity. World Journal of Social Sciences, Vol. 2. No. 4. Pp. 114.

Greyser, S. a. (2009). Corporate brand reputation and brand crisis management. Management Decision, 47(4), 590-602.

Haig, M. (2003) Brand Failures: The Truth About the 100 Biggest Branding Mistakes of All Time.

Hair, J. F., Babin, B., Money, A. H., \& Samouel, P. (2003). Essentials of Business Research Method. United States of America: John Wiley \& Sons, Inc.

Hankinson, P, Lomax, W, \& Hand, C. (2007). The time factor in re-branding organizations: Its effects on staff knowledge, attitudes and behaviour in UK charities. Journal of Product and Brand Management, vol. 16, no. 4, 236246.

Hankinson, P. \& Lomax, W. (2006). The effects of rebranding large UK charities on staff knowledge, attitudes and behaviour. International Journal of Nonprofit and Voluntary Sector Marketing, 11 (3), 193-207. 
Hankinson, P. \& Lomax, W. (2006). The effects of rebranding large UK charities on staff knowledge, attitudes and behaviour. International Journal of Nonprofit and Voluntary Sector Marketing, 11 (3), 193-207.

Hankinson, P. \& Lomax, W. (2006). The effects of rebranding large UK charities on staff knowledge, attitudes and behaviour. International Journal of Nonprofit and Voluntary Sector Marketing, 11 (3), 193-207.

Herbig, P., \& Milewicz, J. (1997). The relationship of reputation and credibility to brand success. Pricing strategy and practice , 25-29.

Ing, G. P. (2012). Corporate rebranding and the effects on consumers' attitude structure. International Journal of Business and Society, 13(3), 255-278.

Kapferer, J. N. (2004). The new strategic brand management: Creating and sustaining brand equity long term,term. London: Kogan page.

Keller, K. L. (1999). Managing brand for long run: Brand reinforcement and revitalization strategy. California Management Review, 41, (3), 102-24.

Keller, K.L. (1993) ‘Conceptualizing, measuring and managing customer-based brand equity’, Kogan, Sterling, VA.

Kotler, P., Keller, L. K., Ang, S. H., Leong, S. M., \& Tan, C. T. (2012). Marketing Management : An Asian Perspective. Singapore: Pearson Education South Asia Pte Ltd.

Krejcie, R., \& Morgan, D. (1970). Determining sample size for research activities. Educational and Psychological Manangement, 30, 607-610.

Kumar,MS. M., Pasha, M. S., \& Prakash, B. (2015). The Changing Scenario of Telecom Industry in India:A Special Reference Selected Telecom Companies. Indian Journal ofApplied Research, Volume : 5 Issue : 6 162-164.

Le, A. N., Cheng, J. M., Kuntjara, H., \& Lin, C. T.-J. (2014). Corporate rebranding and brand preference:Brand name attitude and product expertise as moderators. Asia Pacific Journal of Marketing and Logistics , 602-620.

Makasi, A., Govender, K., \& Madzorera, N. (2004). Re-branding and Its effects on consumer perceptions: A case study of a zimbabwean bank. Mediterranean. Journal of Social Sciences, 5 (20), 25-82.

Malaysian Airlines System. (2014, August 28). Malaysian Airlines System. Retrieved August 8, 2015, from MAS: Press Room: http://www.malaysiaairlines.com/de/de/corporate-info/press-room/latest/mas_q2_2014_result.html.

Mason, A. M. (2014). The Impact of Media Frames and Treatment Responsibility within the Situational Crisis Communication Theory Framework. Corporate Reputation Review , 78-90.

Merrilees, B., \& Miller, D. (2008). Principles of corporate rebranding. European Journal of Marketing , 537 - 552.

Meulenberg, M., Pennings, J., \& Wansink, B. (2002). A note on modeling consumer reactions to a crisis: the case of the mad cow disease. International Journal of Research in Marketing, Vol. 19 No. 1, pp. 91-100.

Muzellec, L., \& Lambkin, M. (2006). Corporate rebranding: Destroying, transferring or creating brand equity. European Journal of Marketing, 40 (7/8), 803-824.

Muzellec, L., \& Lambkin, M. (2006). Corporate rebranding: Destroying, transferring or creating brand equity. European Journal of Marketing, 40 (7/8), 803-824.

Muzellec, L., Doogan, M., \& Lambkin, M. (2003). Corporate rebranding: An exploratory review. Irish Marketing Review, 16 (2), 31-40.

Muzellec, L., Doogan, M., \& Lambkin, M. (2003). Corporate rebranding: An exploratory review. Irish Marketing Review, 16 (2), 31-40.

Nunnally, J. C. (1975). Psychometric Theory: 25 years ago and now. Educational Researcher , 7-14 
Oliver, R. L. (1999). Whence consumer loyalty. Journal of Marketing, 33-44.

Opuni, F. F., Baffoe, M. S., \& Adusei, E. P. (2013). The effectiveness of rebranding as a comparative study of ghanaian business using the principles of corporate rebranding. Journal of Marketing and Management, 4 (2), 69.

Papadakis, Y. (2006). The impact of genuine uncertainty on productionn desicions unfluencing consumer safety. Working Paper .

Paraskevas, A. (2006). Crisis management or srisis response system?: A complexity science approach to organizational crises. Management Desicion, 892-907.

Petburikul, K.,. "The Impact of Crporate Rebranding of West Viginia Higher Education." RU International Journal, 2009.

Priporas, C.-V., \& Vangelinos, G. (2008). Crisis management in pharmaceuticals: evidence from Greece. International Journal of Pharmaceutical and Healthcare Marketing, 88-102.

Raghuvanshi, G., \& Ng, J. (2014, April 6). The Wall Street Journal. Retrieved August 8, 2015, from Malaysia Airlines Says Priority Is Families of the Missing, Though Ticket Sales Fall: http://www.wsj.com/articles/SB10001424052702303532704579483060366249526.

Rea, B., Wang, Y. J., \& Stoner, J. (2014). When a brand caught fire : the role of brand equity in product harm crisis. Journal of Product \& Brand Management, 532-542.

Reddy, S. K., Reddy, U. M., \&Venkatesulu, K. (2016). Brand revitalization. International journal of science technology and management, 5(1), 321-326.

Rhee, M. (2009). Does Reputation Contribute to Reducing Organizational Errors? A Learning Approach. Journal of Management Studies, 667 - 703.

Roy, S., \& Sarkar, S. (2015). To brand or to rebrand: Investigating the effects of rebranding on brand equity and consumer attitudes. Journal of Brand Management , 340-360.

Sekaran, U. (2003). Research Methods For Business : A Skill Building Approach. Singapore: Replika Press Pvt. Ltd.

Sekaran, U., \& Bougie, R. (2010). Research methods for business: Building approach (5th ed.). West Susses, UK: Wiley.

Selnes, F. (1998). Antecedents and consequences of trust and satisfaction in buyer-seller relationships. European Journal of Marketing, 305-322.

Sengupta, S. A., Balaji, M., \& Krishnan, B. C. (2015). How customers cope with service failure? A study of brand reputation and customer satisfaction. Journal of Business Research, 10-20.

Singh, A. K., Tripathi, V., \& Yadav, P. (2012). Rebranding and organisational performance: Some issues of relevance. American Journal of Sociological Research, Vol. 2 No. 5, 90-97. doi: 10.5923/j.sociology.20120205.01.

Siomkos, G. J. (1999). On achieving exoneration after a product safety industrial crisis. Journal of Business \& Industrial Marketing, 17 - 29.

Teh, G. (2009). Rebranding and Impact Toward Brand Equity. Kuala Lumpur: Kuala Lumpur Infrastructure University College.

Tevi, C. A., \& Otubanjo, O. (2013). Understanding corporate re-Branding: An evolution theory perspective. Retrieved from www.ssrn.com: http;//www.ssrn.com/

Veloutsou, C. (2015). Brand evaluation, satisfaction and trust as predictors of brand loyalty: the mediator-moderator effect of brand relationships. Journal of consumer marketing, 405-421. 
Walsh, M. F. (2005). Consumer response to logo shapenredesign: the influence of brand commitment. Doctoral dissertation, University of Pittsburgh.

Yubo, C., Shankar, G., \& Yong, L. (2009). Does a Firm's Product-Recall Strategy Affect Its Financial Value? An Examination of Strategic Alternatives During Product-Harm Crises. Journal of Marketing, 214-226.

Zahid, S., \& Raja, N. S. (2014). Effect of rebranding and repositioning on brand equity considering brand loyalty as a mediating variables. IOSR Journal of Business and Management, 16 (1), 58-63.

Zayerkabeh, S., Albabayi, A., \& Abdoli, M. (2012). Studying the Effect of Brand Credibility and Brand Prestige on Brand Loyalty. Australian Journal of Basic and Applied Sciences, 160-166.

Zikmund, W. G. (2003). Business Research Method (7th ed.). Toronto: Dryden Press. 